\title{
SCREANING STUDY FOR THE PREVALENCE OF EMOTIONAL AND BEHAVIORAL PROBLEMS AMONG SCHOOL CHILDREN
}

\section{IN IRAQ}

\author{
Dr. Ibrahim Safaa kareem, M.B.Ch. B \\ F.A.B.H.S. Psych (Fellow of Arab Board of Health Specializations of Psychiatry) \\ Alimam Alhussein Teaching Hospital/Nasiriya-Iraq
}

\begin{abstract}
BACKGROUND

Child\& adolescent psychiatric disorders

are common and treatable, but oftenly go undetected therefore, remain untreated. Epidemiological information about prevalence of child mental health problems is essential to inform policy and public health practice. There have been few such studies in Arab countries and few in Iraq.

\section{PATIENTS \&METHODS}

A sample size of 300 students 150 male

\& 150 female were chosen randomly at ages between 15-17 years and were asked to complete the strengths \& difficulties questionnaire. The parents were asked to complete other version of strength and difficulty questionnaire. The study was carried out in the
\end{abstract}

centre of Baghdad city in AL-Karrada sector in secondary schools. By using the multi informant method for strengths and difficulties questionnaire, Using 2 tools

-Strengths \& difficulties questionnaire (SDQ) in 2 versions one for students \& one for their parents (informant).

-Iraq trauma questionnaire presents only for students.

RESULTS

Total difficulty score in student's report was $(16 \%)$, while in parent's report was (26.33\%). Emotional problems in females were the highest $(30.66 \%)$, prosocial problems were the lowest $(4 \%)$. In male, conduct problems were $(12 \%)$ which is the highest one, while the peer problems were the lowest $(3.33 \%)$. From all students (63.66\%) were exposed to traumatic 
events. From these, (44\%) of them witnessed car explosion, (47.33\%) has 1-2 traumatic events in the past 11 years. Hundred percent of female who exposed to $5 \&$ more events has emotional \& behavioral problems. Hundred percent of male who exposed to $7 \&$ more events has emotional \& behavioral problems

\section{CONCLUSIONS}

The emotional problems in females and conduct problems in males the highest $\&$ needs more attention\& management. Increasing number of traumatic events will increase the emotional\& behavioral problems in children.

INTRODUCTION

Emotional and behavioral problems are the most prevalent chronic mental health problems of childhood and often have serious negative consequences for a child's academic achievement and social \& psychological development. [1]. Mental health problems in children and young people may be defined as abnormalities of emotion, behavior or social relationships sufficiently marked or prolonged to cause suffering. Childhood emotional developmental disorders, behavioral problems and mental illness are under recognized, often remain untreated and are associated with significant morbidity and mortality, leading to

lifelong disability [2].

Strengths and difficulties questionnaire

(SDQ) as a screening tool has been used for epidemiologic studies in over 40 countries \& has been translated into Arabic \& validated. [3]. Many environmental factors can affect mental health, including exposure to violence, extreme stress, and the loss of an important person [4]. Predictions based on multi-informant SDQ potentially provide a cheap and easy method for detecting children in the developing world with significant mental health problems $[5,6]$. Behavioral problems in childhood are frequently interpreted as misbehavior that can be managed by punishment or reward within the family. Within the overcrowded schools, teachers are less likely to differentiate between opmental disorder, children with a devel adjustment disorder or mild mental retardation

$$
[7,8,9] \text {. }
$$

Mental disorders account for a large proportion of the diseases burden in young people in all societies\& cultural groups. Children who had dropped out of school had more behavioral problems $[10,11]$.

Prevalence rates of child psychopathology have been found to vary, depending on the 
population and measures, with most research findings arising from western societies [12, 13]. Most typically, when a child or adolescent is described as having an emotional disorder, this means that he or she has a diagnosed disorder of mood or anxiety. These kinds of disorders are characterized by feelings of intense internal and/or emotional distress that last, either continually or intermittently, for a period of months or years extending sometime to adulthood [14].

As countries move through

developmental transition, patterns of morbidity change and come to resemble those of more developed nations [15]. Prevention and treatment of youths` mental disorders are important, not just for to diminish their present problems but to improve their functioningin adulthood\& make a benefitfor their society.

Socioeconomic, political and cultural changes may affect the physical, mental health and life style of youths [16]. Boys were more likely to be hyperactive and have conduct and social difficulties. Girls had higher rates of emotional problems [17]. The only way to achieve effective treatment is through accurate assessment. Emotional and behavioral disorders frequently lead to poor school attendance and performance and to dropping-out of school [18]. Parents are frequently the first adults to identify that a child has a serious emotional or behavioral problem. Surveys that collect information from parents also have the advantage of using a respondent who is knowledgeable about other aspects of a child's life, including the child's sociodemographic characteristics, developmental conditions, and use of educational and health care services [19]. If we spent more time on the evaluation of healthy youngsters, in addition to referrals to appropriate treatment programs are more rapid, it could potentially increase treatment capacity [20]. The SDQ is a user-friendly screening questionnaire, which can be used to assess behavioral problems and mental health disorders and we used it here to assess the prevalence of those disorders in Iraq. The questionnaire consists of 25 questions subdivided into five categories: conduct; hyperactivity; peer problems; emotional; and, prosocial, with five questions in each scale [21]. The Strengths and

Difficulties.Questionnaire (SDQ) is widely used as a screening tool for psychiatric disorders in clinical practice. It assesses child and 
adolescent behavior, as well as the impact/impairment of any symptoms, based on information from parents or teachers and selfreport. We included adolescents' self-reports because we believe they can provide information on variables such as emotional states that other raters cannot. The overarching goal of the study was to use multi-informant data sources [22]. The strengths \& difficulties questionnaire is a useful brief measure of the adjustment and psychopathology of children and adolescents like mood or anxiety disorders [23].

\section{PATIENTS\& METHODS}

We have conducted a prevalence study using the strengths\&difficulties questionnaire (SDQ) \& Iraq trauma questionnaire (ITQ) in order to provide accurate and contemporaneous data on rates of emotional and behavioral symptoms and of probable psychiatric disorders among children in secondary school aged 15 17 years old. I select these limited age groups because they are more orient to trauma and express their symptoms precisely.

SETTING

The study was carried out in the centre of Baghdad city (urban area) in AL-Karrada quarter in secondary schools.
A sample size of 300students, 150 male

$\& 150$ female from two schools at ages between 15-17 years old. Also we informed students to give another version of SDQ for their parents.

DATA COLLECTION by using:

Strengths\&difficulties questionnaire (SDQ)

in 2 versions one for students \& one for their parents. The SDQ is standardized by Robert Goodman, 2005.Total difficulties (normal+borderline) are unlikely mental disease cases while the abnormal one means likely mental diseases depending on cutoff point described bellow. All scales except (prosocial) are summed to generate a total difficulties score ranging from 0 to 40 . The impact supplement enquires about chronicity, distress, social impairment, and burden for others. Iraq trauma questionnaire (ITQ) which includes many questions about the traumatic events happened to students in the last $11 \mathrm{yrs}$.

STATISTICAL-ANALYSIS

Predicted psychiatric diagnoses were classified at the total difficulties score values where the normal \& borderline scores are not likely mental health disease cases while abnormal score being the likely mental health disorder cases. We used the program SPSS for statistical analysis, being considered a 
significant difference $(p=0.05)$ for the chi-

square.

RESULTS

A total sample consist of 300 students

150 female \& 150 male with their total parents

300 was included in this project \& chosen

randomly.
Table 1 shows that the total difficulties in female are $(19.33 \%)$ are more than male 12.66\%). The prevalence of emotional \& behavioral problems in total student's sample was $(16 \%)$. In assessment of total number of students, we will find that the highest problem was in emotions $(18.33 \%) \&$ the lowest was peer problems $(6 \%)$.

Table 1: subscales results of SDQ among students.

\begin{tabular}{|c|c|c|c|}
\hline Subscale of SDQ & $\begin{array}{c}\text { Female } \\
\text { students } \\
\text { No. }(\%)\end{array}$ & $\begin{array}{c}\text { Male students } \\
\text { No. }(\%)\end{array}$ & $\begin{array}{l}\text { Total students } \\
\text { No. }(\%)\end{array}$ \\
\hline $\begin{array}{r}\text { Emotional problems } \\
\text { Normal } \\
\text { Borderline } \\
\text { Abnormal }\end{array}$ & $\begin{array}{l}83(55.33) \\
21(14) \\
46(30.66)\end{array}$ & $\begin{array}{c}131(87.33) \\
10(6.66) \\
9(6)\end{array}$ & $\begin{array}{l}214(71.3) \\
31(10.33) \\
55(18.33)\end{array}$ \\
\hline $\begin{array}{r}\text { Conduct problems } \\
\text { Normal } \\
\text { Borderline } \\
\text { Abnormal }\end{array}$ & $\begin{array}{c}111(74) \\
17(11.33) \\
22(14.66)\end{array}$ & $\begin{array}{c}113(75.33) \\
19(12.66) \\
18(12)\end{array}$ & $\begin{array}{l}224(74.66) \\
36(12) \\
40(13.33)\end{array}$ \\
\hline $\begin{array}{r}\text { Hyperactivity symptoms } \\
\text { Normal } \\
\text { Borderline } \\
\text { Abnormal }\end{array}$ & $\begin{array}{l}114(76) \\
10(6.66) \\
26(17.33)\end{array}$ & $\begin{array}{c}128(85.33) \\
12(8) \\
10(6.66)\end{array}$ & $\begin{array}{c}242(80.66) \\
28(9.3) \\
36(12)\end{array}$ \\
\hline $\begin{array}{r}\text { Peer problems } \\
\text { Normal } \\
\text { Borderline } \\
\text { Abnormal }\end{array}$ & $\begin{array}{c}103(68.66) \\
34(22.66) \\
13(8.66)\end{array}$ & $\begin{array}{c}114(76) \\
31(20.66) \\
5(3.33)\end{array}$ & $\begin{array}{c}217(72.33) \\
65(21.66) \\
18(6)\end{array}$ \\
\hline $\begin{array}{r}\text { Prosocial scale } \\
\text { Normal } \\
\text { Borderline } \\
\text { Abnormal }\end{array}$ & $\begin{array}{c}143(95.33) \\
1(0.66) \\
6(4)\end{array}$ & $\begin{array}{l}129(86) \\
11(7.33) \\
10(6.66)\end{array}$ & $\begin{array}{c}272(90.66) \\
12(4) \\
16(5.33)\end{array}$ \\
\hline $\begin{array}{l}\text { Total difficulties } \\
\text { Normal (unlikely mental disease) } \\
\text { Border (unlikely mental disease) } \\
\text { Abnormal (likely mental disease) }\end{array}$ & $\begin{array}{c}90(60) \\
31(20.66) \\
29(19.33)\end{array}$ & $\begin{array}{l}115(76.66) \\
16(10.66) \\
19(12.66)\end{array}$ & $\begin{array}{c}205(68.33) \\
47(15.66) \\
48(16)\end{array}$ \\
\hline $\begin{array}{r}\text { Impact score } \\
\text { Normal } \\
\text { Borderline } \\
\text { Abnormal }\end{array}$ & $\begin{array}{c}81(54) \\
11(7.33) \\
58(38.66)\end{array}$ & $\begin{array}{c}100(66.66) \\
14(9.33) \\
36(24)\end{array}$ & $\begin{array}{l}181(60.33) \\
21(7) \\
94(31.33)\end{array}$ \\
\hline
\end{tabular}


$P$ value $=<0.05$ is significant (using person chi-squared test at 0.05 level of significant) regarding total difficulty score.

Table 2 The Parents of female show that all SDQ subscales were higher than parents of male. The emotional problems in female were the highest one.

Table 2: subscales of SDQ parents

\begin{tabular}{|c|c|c|c|}
\hline Subscale of SDQ & $\begin{array}{r}\text { Parens of } \\
\text { Female } \\
\text { students } \\
\text { No. }(\%)\end{array}$ & $\begin{array}{r}\text { Parents of } \\
\text { Male students } \\
\text { No. }(\%)\end{array}$ & $\begin{array}{r}\text { Total parents } \\
\text { No. }(\%)\end{array}$ \\
\hline \multicolumn{4}{|l|}{ Emotional problems } \\
\hline Normal & $65(43.33)$ & $111(74)$ & $176(58.66)$ \\
\hline Borderline & $21(14)$ & $17(11.33)$ & $38(12.66)$ \\
\hline Abnormal & $64(42.66)$ & $22(14.66)$ & $86(28.66)$ \\
\hline \multicolumn{4}{|l|}{ Conduct problems } \\
\hline Normal & $77(51.33)$ & $107(71.33)$ & $184(61.33)$ \\
\hline Borderline & $20(13.33)$ & $22(14.66)$ & $42(14)$ \\
\hline Abnormal & $53(35.33)$ & $21(14)$ & $74(24.66)$ \\
\hline \multicolumn{4}{|l|}{ Hyperactivity symptoms } \\
\hline Normal & $109(72.66)$ & $119(79.33)$ & $228(76)$ \\
\hline Borderline & $21(14)$ & $18(12)$ & $39(13)$ \\
\hline Abnormal & $20(13.33)$ & $13(8.66)$ & $33(11)$ \\
\hline \multicolumn{4}{|l|}{ Peer problems } \\
\hline Normal & $77(51.33)$ & $83(55.33)$ & $160(53.33)$ \\
\hline Borderline & $32(21.33)$ & $35(23.33)$ & $67(22.33)$ \\
\hline Abnormal & $41(27.33)$ & $32(21.33)$ & $73(24.33)$ \\
\hline \multicolumn{4}{|l|}{ Prosocial scale } \\
\hline Normal & $143(95.33)$ & $129(86)$ & 272 (90.66) \\
\hline Borderline & $2(1.33)$ & $9(6)$ & $11(3.66)$ \\
\hline Abnormal & $5(3.33)$ & $12(8)$ & $17(5.66)$ \\
\hline \multicolumn{4}{|l|}{ Total difficulties } \\
\hline Normal (unlikely mental & $72(48)$ & $108(72)$ & $180(60)$ \\
\hline disease) & $21(14)$ & $20(13.33)$ & $41(13.66)$ \\
\hline $\begin{array}{r}\text { Border (unlikely mental } \\
\text { disease) }\end{array}$ & $57(38)$ & $22(14.66)$ & 79 (26.33) \\
\hline \multicolumn{4}{|l|}{$\begin{array}{r}\text { Abnormal (likely mental } \\
\text { disease) }\end{array}$} \\
\hline \multicolumn{4}{|l|}{ Impact score } \\
\hline Normal & $112(74.66)$ & $114(76)$ & $226(75.33)$ \\
\hline Borderline & $10(6.66)$ & $12(8)$ & $22(7.33)$ \\
\hline
\end{tabular}


utjimed@utq.edu.iq

\begin{tabular}{|r|r|r|r|}
\hline Abnormal & 28 (18.66) & 24 (16) & 52 (17.33) \\
\hline
\end{tabular}

The students who exposed to trauma were $(63.66 \%) \&$ those who are not are $(36.33 \%)$. events $(47.33 \%)$ while the lowest $(1 \%)$ was 7 or more events.

As described in table 3, the largest

proportion of students was exposed to 1-2

Table 3: the frequency of traumatic events among both gender in students during the past 11 yrs (2003-2014).

\begin{tabular}{|r|r|r|r|}
\hline $\begin{array}{r}\text { No. of traumatic } \\
\text { events }\end{array}$ & $\begin{array}{r}\text { Female students } \\
\text { No. (\%) }\end{array}$ & $\begin{array}{r}\text { Male students } \\
\text { No. (\%) }\end{array}$ & $\begin{array}{r}\text { Total students } \\
\text { No. (\%) }\end{array}$ \\
\hline $\mathbf{0}$ & $49(32.66)$ & $60(40)$ & $109(36.33)$ \\
\hline $\mathbf{1 - 2}$ & $75(50)$ & $67(44.66)$ & $142(47.33)$ \\
\hline $\mathbf{3 - 4}$ & $22(14.66)$ & $18(12)$ & $40(13.33)$ \\
\hline $\mathbf{5 - 6}$ & $2(1.33)$ & $4(2.66)$ & $6(2)$ \\
\hline $\mathbf{7}$ or more & $2(1.33)$ & $1(0.666)$ & $3(1)$ \\
\hline total & $150(100)$ & $150(100)$ & $300(100)$ \\
\hline
\end{tabular}

$\mathrm{P}$ value $=<0.05$ is significant (using person chi-squared test at 0.05 level of significant).

Table 4 clarify how the traumatic events affecting the mental health state. disease, while only $(8.163 \%)$ of those who were not exposed to trauma has likely mental illness.

All (100\%) female students with five and more traumatic events have likely mental health

Table 4: relation between frequency of traumatic events \& total difficulties score (TDS) in

female students.

\begin{tabular}{|c|c|c|c|c|}
\hline $\begin{array}{c}\text { No. of } \\
\text { Events }\end{array}$ & $\begin{array}{c}\text { Total female students } \\
\text { no. according to no. } \\
\text { of events. }\end{array}$ & $\begin{array}{c}\text { TDS } \\
\text { Normal } \\
\text { No. }(\%)\end{array}$ & $\begin{array}{c}\text { TDS } \\
\text { Borderline } \\
\text { No. }(\%)\end{array}$ & $\begin{array}{c}\text { TDS } \\
\text { Abnormal (likely } \\
\text { mental disease) } \\
\text { No. }(\%)\end{array}$ \\
\hline $\mathbf{0}$ & 49 & $38(77.55)$ & $7(14.285)$ & $4(8.163)$ \\
\hline $\mathbf{1 - 2}$ & 75 & $40(53.33)$ & $18(24)$ & $17(22.66)$ \\
\hline $\mathbf{3 - 4}$ & 22 & $11(50)$ & $5(22.72)$ & $6(27.27)$ \\
\hline $\mathbf{5 - 6}$ & 2 & $0(0)$ & $0(0)$ & $2(100)$ \\
\hline $\mathbf{7}$ or more & 2 & $0(0)$ & $0(0)$ & $2(100)$ \\
\hline
\end{tabular}


$P$ value $=>0.05$ is not significant (using person chi-squared test at 0.05 level of significance).

Table 5 clarify that $(100 \%)$ of male students who were exposed to seven or more traumatic events have likely mental disease, while only (5\%) of those who were not exposed to traumatic events have likely mental illness.

Table 5: relation between frequency of traumatic events \& total difficulties score (TDS) in male students.

\begin{tabular}{|c|c|c|c|c|}
\hline $\begin{array}{c}\text { No. of } \\
\text { Events }\end{array}$ & $\begin{array}{c}\text { Total male students } \\
\text { no. according to no. } \\
\text { of events. }\end{array}$ & $\begin{array}{c}\text { TDS } \\
\text { Normal } \\
\text { No. }(\%)\end{array}$ & $\begin{array}{c}\text { TDS } \\
\text { Borderline } \\
\text { No. }(\%)\end{array}$ & $\begin{array}{c}\text { TDS } \\
\text { Abnormal (likely } \\
\text { mental disease) } \\
\text { No. }(\%)\end{array}$ \\
\hline $\mathbf{0}$ & 60 & $52(86.66)$ & $5(8.33)$ & $3(5)$ \\
\hline $\mathbf{1 - 2}$ & 67 & $48(71.64)$ & $10(14.92)$ & $9(13.43)$ \\
\hline $\mathbf{3 - 4}$ & 18 & $10(55.55)$ & $1(5.55)$ & $7(38.88)$ \\
\hline $\mathbf{5 - 6}$ & 4 & $2(50)$ & $0(0)$ & $2(50)$ \\
\hline $\mathbf{7}$ or more & 1 & $0(0)$ & $0(0)$ & $1(100)$ \\
\hline
\end{tabular}

\section{$P$ value $=>0.05$ is not significant (using person chi-squared test at 0.05 level of significance).}

DISCUSSION

The main objective of this study was to provide a generalized assessment of mental health of Iraqi adolescents aged 15-17 years We found that total difficulty using the SDQ score was (16\%) in students, while in parents' report $(26.33 \%)$. In female, the emotional problems were the highest subscale $(30.66 \%)$. In male, the conduct problems were the highest subscale (12\%). So we must bring attention toward emotional problems in female \& conduct problems in male students. Table 1 and 2 show that both female students and their parents reveal conduct and hyperactive symptoms percent more than revealed by males and their parents and this probably because the s symptoms 'parents overestimate their daughter due to hysterionic symptoms which is more in 
girls or due to nonunderstanding the questions by both of them and may be not accurate but this was the real result so I cannot change it and I prefer to leave it as this.

\section{COMPARISONS WITH OTHER STUDIES:}

1- Our findings are comparable with that in Gaza strip study [13], the emotional problems were higher $(34.9 \%)$, conduct problems were higher (22.7\%), hyperactivity symptoms are less than our results $(8.5 \%)$, total difficulties score was less than our results $(14.2 \%)$.

2- In other study done in French schools [14], the results were that the prevalence of emotional disorders among girls is typically found to be higher than boys, while the prevalence of behavioral disorders (conduct, hyperactivity, peer, prosocial) are higher among boys than girls.

3- In one study done in Egypt [15]. Results was higher than our results in the follows: Emotional problems (21.2\%), conduct problems (25.3\%), peer problems $(33.8 \%)$, prosocial problems $(11.8 \%)$, TDS (20.6\%).
4- In Isfahan - Iran [16], all results were much higher than our results. $(26 \%)$ has likely mental health disease (TDS).

5- A study conducted in USA [19] reveals a (7\%) likely mental illness which means that there is a good follow up for that section of community.

6- A study conducted in Ireland [21] reveals that $(13.6 \%)$ of children has conduct \& hyperactivity problems which is nearly similar in our results, while is much less in other subscales.

7- Ribeirao preto [22] found that all emotional \& behavioral problems are double of our results while the impacts due to it is much less $(10.2 \%)$.

8- Other study in United Kingdom [23], found that TDS are less than our results in Iraq.

The differences between all above studies and our study may be due to that the other countrie's citizens -parent or children- are more oriented to health issues and more alert to scales which is widely used in many society institutions so their results of difficulties are less than ours. Also there are a huge difference in residence area, culture, educational level, 
environment, economic, degree of feeling secure \&war problems than our country.

\section{TRAUMATIC EVENTS:}

The majority of those who were exposed to trauma $(47.33 \%)$ had 1-2 trauma events in the last 11 years from 2003, a minority (1\%) were exposed to seven or more events. There are other studies about traumatic events in Iraq like:

Majeed, J (2011) [24] His study showed that

1- About $73 \%$ of students were exposed to trauma \& $27 \%$ not exposed.

2- Majority (49\%)was exposed to 1-2 events \& the minority (1\%) was exposed to 7 or more events.

Abdul Aziz, B (2010) [25] in her study about rates of trauma events reveals:

From all students, (5.6\%) has 1-2 events, $(36.9 \%)$ has 11 or more events. The difference of results in this study is related to the personal aspect of researcher whom did not clearify the causes of difference. Also, this research was carried out when there is a high explosion accidents happened in this year and in this city.
CORRELATION BETWEE THE NUMBER OF

TRAUMATIC EVENTS AND THE STRENGTHS AND DIFFICULTIES QUESTIONNAIRE (SDQ):

Hundred percent of female who had exposed to 5-6 events \& 7 or more events are likely mentally ill. Hundred percent of male with 7 or more events are likely mental disease. So both male \& female students have a mental health issue after they were exposed to more traumatic events.

\section{CONCLUSIONS}

1- From all participants studied, 16\% had an abnormal SDQ score (likely mental illness).

2- Emotional problems were the highest of SDQ subscales in Iraq (18.33\%) which needs more attention.

3- Both male\& female students have more mental health issues after they were 
Thi-Qar Medical Journal (TQMJ): Vol.(11), No.(1), 2016

utjmed@utq.edu.iq

exposed to more traumatic events in proportional relation. 


\section{REFERENCE}

1-AbouNazel MW, Fahmy SI, Younnis IA.et al (1991) A study of depression among Alexandria preparatory school adolescents. J Egypt Public Health Assoc 66:649-674.

2-Cummins C, McMaster C (2006) Child Mental \& Emotional Health: A Review of Evidence. Health service executive.

3-Eapen V, al-Gazali L, Bin-Othman S. et al (1998) Mental health problems among schoolchildren in United Arab Emirates: prevalence and risk factors. J Am Acad Child Adolesc Psychiatry $37(8): 880-886$.

4-Goodman R, Renfrew D, Mullick MSI (2000) Predicting type of psychiatric disorder from strengths and difficulties questionnaire (SDQ) scores in child mental health clinics in London and Dhaka. Eur Child Adolesc Psychiatry 9:129-134.

5-Mathai J, Anderson P, Bourne A (2004) Comparing psychiatric diagnoses generated by the strengths and difficulties questionnaire with diagnoses made by clinicians. Aust NZ J Psychiatry 38:639-643.

6-Meltzer H, Gatward R, Goodman R. et al (2000) Mental health of children\& adolescents in Great Britain. The Stationary Office, London.

7-Mullick MS, Goodman R (2005) The prevalence of psychiatric disorders among 5-10 year olds in rural, urban, slum areas in Bangladesh: an exploratory study. Soc Psychiatry PsychiatrEpidemiol 40(8):663-671.

8-Okasha A (2004) Focus on psychiatry in Egypt. British Journal of Psychiatry 185:266-272.

9-Okasha A, Bishri Z, Seif el Dawla A et al (1999) Anxiety symptoms in an Egyptian sample: children and adolescents. Curr Psychiatry 6:356-368.

10- Patel V, Flisher AJ, Hetrik S. et al (2007) mental health of young people: a global public-health challenge. Lancet 369:1302-1313.

11- Rahim SIA, Cederblad M (1986) Effects of rapid urbanization on child behaviour and health in a part of Khartoum, Sudan - II. Psycho-social influences on behaviour. SocSci Med 22:723730.

12- Samad L, Hollis C, Goodman R. et al (2005) Child and adolescent psychopathology in a developing country: testing the validity of the strengths and difficulties questionnaire (urdu version). Int J Methods Psychiatr Res 14(3):158-166.

13- Thabet AA, Stretch D, Vostanis P (2000) Child mental health problems in Arab children: application of the strengths and difficulties questionnaire. Int J Soc Psychiatry 46(4):266-280.

14- Fombonne E. (1994) The Chartres studies: I. Prevalence of psychiatric disorders among French school-aged children. British Journal of Psychiatry, 164, 69-79. 


\section{utjmed@utq.edu.iq}

15- AbdElhamid A, Howe A, Reading R (2008) prevalence of emotional \& behavioral problems among 6-12 yr old children in Egypt.soc psych psychepidemiology DOI 10.1007/s00127-0080394-1.

16- Arman S, Keypour M, Maracy MR. et al (2012) Epidemiological study of youth mental using strengths \& difficulties questionnaire (SDQ). short psych commun 14(6):371-75.

17- Imran N, Sattar A, Amjad N. et al (2009) Psychological problems in children of parents with mental illness: A comparative study from Lahore, Pakistan. Pak J Med Sci;25(6):895-900.

18- Abdel-Fattah MM, Asal AA, AL-Asmary SM, et-al (2004) Emotional and Behavioral Problems Among Male Saudi Schoolchildren and Adolescents Prevalence and Risk Factors. German Journal of Psychiatry. ISSN 1433-1055

19- Pastor PN, Reuben CA, Duran CR (2012) Identifying Emotional and Behavioral Problems in Children Aged 4-17 Years: United States, 2001-2007.national health statistics reports no.48.

20- Alyahri A, Goodman R (2006) Validation of th Arabic strengths and difficulties questionnaire and the development and wellbeing assessment. East Mediterr Health J 12(Suppl 2): S138S146.

21- Greally P, Kelleher I, Murphy J. et al (2010) Assessment of the mental health of Irish adolescents in the community. Royal College of Surgeons in Ireland Student Medical Journal; 3: 33-35.

22- Cury CR, Golfeto JH. (2003) Strengths and difficulties questionnaire (SDQ): a study of school children in RibeirãoPreto. US national library of medicine 25(3)139-45.

23- Goodman R, Ford T, Simmons H. et al (2000) Using the Strengths and Difficulties Questionnaire (SDQ) to screen for child psychiatric disorders in a community sample. Br J Psychiatry.177:534-9.

24- Majeed, J (2011). The impact of war and violence on mental health of a sample of adolescent students in baghdad, a thesis submitted to the council of Psychiatry-Iraq commission of medical specializations and scientific research supervised by Dr. Numan S. Ali. Page (23-26) unpublished thesis.

25- . Abdul Aziz, B. (2010). Anxiety \& depression among adolescent students in Baghdad A thesis submitted to the council of Psychiatry-Iraq commission of medical specializations and scientific research supervised by Dr. Numan S. Ali. Page (15-16) unpublished thesis.

ان الامراض النفسية عند الاطفال شائعة ومن الممكن علاجها وغالبا ما تكون غير مكتشفة وبالتالي تبقى من دون علاج. المعلومات

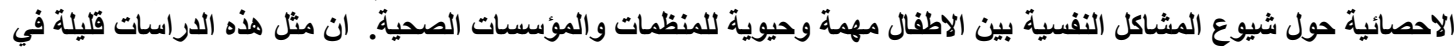

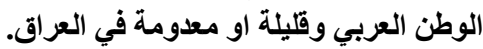
المرضى والطرق:

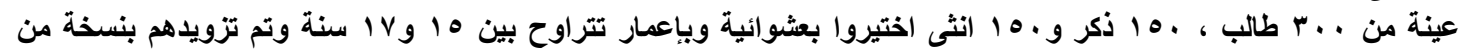

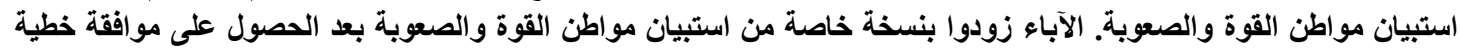
من ذويهم للمشاركة في الاستبيان. 
الاراسة اجريت في مركز مدينة بغداد في قطاع الكرادة في المدارس الثانوية. باستخدام طريقة مصادر المعلومات المتعددة لاستبيان مواطن القوة والصعوبة، وباستخدام مقياسين:

ـ مقياس استبيان مواطن القوة والصعوبة بنسختين أحدهما للطلبة والاخرى للآباء (المصدر للمعلومات).

ـ استبيان الصدمة في العراق وهو للطلاب فقط.

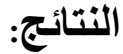

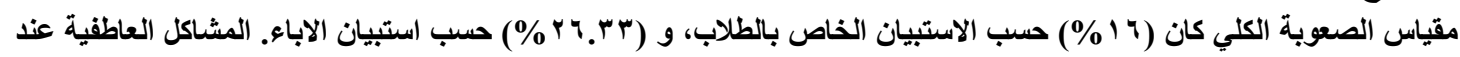

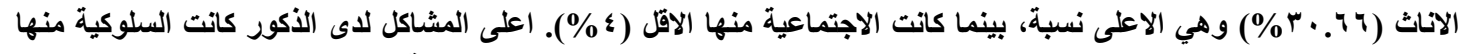

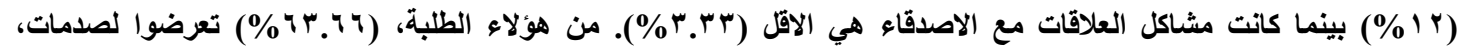

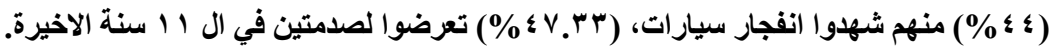

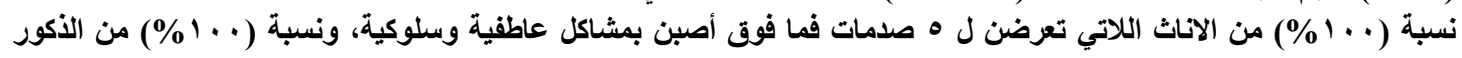

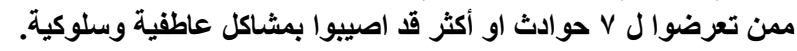
الاستنتاجات:

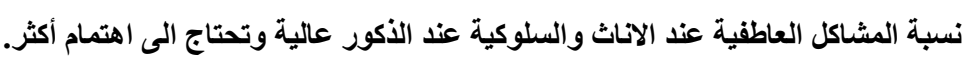

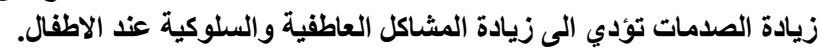

